\title{
DETERMINATION OF PROTONATION CONSTANTS AND STRUCTURAL CORRELATIONS FOR SOME TERTIARY FORMAMIDES AND ACETAMIDES IN SULFURIC ACID WITH UV SPECTROSCOPY
}

\author{
Goran Stojković ${ }^{1, *}$, Elizabeta Dimitrieska-Stojković ${ }^{2}$, Emil Popovski $^{1}$ \\ ${ }^{1}$ Institute of Chemistry, Faculty of Natural Sciences and Mathematics, Ss. Cyril and Methodius University, \\ Arhimedova 5, 1000 Skopje, Republic of Macedonia \\ ${ }^{2}$ Institute for Food, Faculty of Veterinary Medicine, Ss. Cyril and Methodius University, \\ Lazar Pop-Trajkov 5-7, 1000 Skopje, Republic of Macedonia \\ goranst@pmf.ukim.mk, emilp@pmf.ukim.mk, edimitrieska@fvm.ukim.edu.mk
}

\begin{abstract}
The protonation of ten aliphatic amides in sulfuric acid media was studied by UV spectroscopy. The $\mathrm{p} \mathrm{K}_{\mathrm{BH}}{ }^{+}$values and solvation parameters were calculated using Yates and McClelland Method, Excess Acidity Method and Bunnett and Olsen Method. $\mathrm{p}{K_{\mathrm{BH}}}^{+}$values were $-1.44,-1.15,-0.80,-0.32,-1.13$ and -0.80 for formamide, dimethylformamide, diethylformamide, diisopropylformamide, diisobutylformamide and dibutylformamide, respectively. According to the $\mathrm{pK}_{\mathrm{BH}}{ }^{+}$values obtained for acetamide, dimethylacetamide, diethylacetamide and diisopropylacetamide $(-0.57,-0.29,-0.32$ and 0.36 , respectively), analogous acetamides were more basic than formamides. Applying the Hammett's equation, satisfactory correlation could be gained only for some formamides, the basicities of which increased linearly with the inductive effect of the electron donating groups. From Taft's approach, it can be concluded that the polar effect slightly dominates over the steric one. Excellent correlation between $\mathrm{p} \mathrm{K}_{\mathrm{BH}}{ }^{+}$and solvation parameters $m^{*}$ was achieved for formamide, dimethylformamide and diethylformamide. At half- and fullprotonation, better correlation was obtained for formamides than for acetamides.
\end{abstract}

Keywords: UV spectroscopy; formamides; acetamides; protonation constants; Hammett-Taft correlations

\section{ОПРЕДЕЛУВАЊЕ НА КОНСТАНТИТЕ НА ПРОТОНИРАҢЕ И СТРУКТУРНИ КОРЕЛАЦИИ НА НЕКОИ ТЕРЦИЈАРНИ ФОРМАМИДИ И АЦЕТАМИДИ ВО СУЛФУРНА КИСЕЛИНА СО УЛТРАВИОЛЕТОВА СПЕКТРОСКОПИЈА}

Протонирањето на десет алифатични амиди во сулфурна киселина е проучувано со примена на ултравиолетова спектроскопија. Вредностите за $\mathrm{p} K_{\mathrm{BH}+}$ и солватационите параметри се пресметани според методот на Yates и McClelland, методот на вишок на киселост и Bunnett-Olsenовиот метод. Вредностите за $\mathrm{p}_{\mathrm{BH}}{ }^{+}$изнесуваат $-1.44,-1.15,-0.80,-0.32,-1.13$ и -0.80 за формамид, диметилформамид, диетилформамид, диизопропилформамид, диизобутилформамид и дибутилформамид, соодветно. Според вредностите на р $K_{\mathrm{BH}+}$ определени за ацетамид, диметилацетамид, диетилацетамид и диизопропилацетамид $(-0.57,-0.29,-0.32$ и 0.36 , соодветно) аналогните ацетамиди се побазни од формамидите. Со примена на Наmmett-овата равенка добиени се задоволителни резултати само за некои формамиди, чија базност линеарно расте со индуктивниот ефект на електронодонорната група. Од Taft-овскиот пристап може да се заклучи дека поларниот ефект е незначително поголем од стерниот. Постигната е одлична корелација помеѓу вредностите на $\mathrm{p} K_{\mathrm{BH}}{ }^{+}$и солватационите параметри $m^{*}$ за формамид, диметилформамид и диетилформамид. Кај полу- и целосна протонација, подобра корелација е добиена за формамиди отколку за ацетамиди.

Клучни зборови: UV спектроскопија; формамиди; ацетамиди; константи на протонирање; Hammett-Taft-овски корелации 


\section{INTRODUCTION}

Acid-base properties and protonation-deprotonation equilibria are the most widely studied chemical phenomena. The importance for accurate and comparable determination of $\mathrm{p} K$ values resulted in the development and application of many analytical techniques [1]. An accurate knowledge of the protonation behavior of weak bases is required both for structure-reactivity correlations and for a detailed kinetic analysis of hydrolysis [2-5].

Protonation constants of weak organic bases are obtained by analyzing the changes of some physical properties of the observed substrates, starting from free towards protonated base, by increasing the media acidity. However, for carbonyl compounds, such as amides, the situation is more complex since the spectra of one or both forms are usually subjected to substantial medium effects. Both of the commonly applied methods for the study of protonation equilibria (UV-Vis and NMR) are affected to some extent by the medium effects that accompany the acid concentration changes. Various methods have been devised to correct for the medium effect, e.g. CVA - characteristic vector analysis [6-9], PCA - principal component analysis [10-12], TFA - target factor analysis [13-15], etc.

Aliphatic amides can be conveniently studied by NMR spectroscopy [16-22], for which solvent effect can be adequately handled [16]. According to some opinions, UV spectroscopy was considered inappropriate, because UV absorption of aliphatic amides in water solution takes place at $190-200 \mathrm{~nm}$. Additionally, it is subjected to further hypsochromic shift caused by protonation [16]. One of the few methods which is used to determine the basicities of some aliphatic amides is the conductimetric method used by Grant and coauthors [23]. Basicity and solvation of aliphatic amides are intrinsically important parameters for understanding the behavior of biochemical systems. Protonation has an important catalytic role in the hydrolysis of amide bond in peptides. As a consequence, simple amides (for example, formamide) are widely used as model compounds for studying the protonation site in strained amides [24].

The determination of protonation sites in the molecule is an important issue in the observation of protonation equilibria for amides. Many authors have agreed that the $O$-atom from the carbonyl group, compared to the $N$-atom from the amide group, is the predominant protonation site, but there are a few other opinions as well $[17,18]$. In the recent investigations, employing quantum chemical calculations and heteronuclear NMR measurements of carboxylic and non-carboxylic amides, Bagno et al. [25] have concluded that, generally (with few exceptions, e.g. sulfonamides, sulfinamides and sulfenamides), amides are protonated on the acid residue. On this basis, the protonation reaction of the investigated aliphatic amides could be represented by a mechanism in Scheme 1 .<smiles>[R]C(=O)N([R])[R]</smiles>

formamides: $R_{1}=H, \quad R_{2}=H, M e, E t, i P r, i B u, B u$

acetamides: $R_{1}=M e, R_{2}=H, M e, E t, i P r$

Scheme 1. Assumed reaction of protonation of aliphatic amides

The present paper reports determination of the protonation constants of ten aliphatic amides of the type $\mathrm{R}-\mathrm{C}(\mathrm{O})-\mathrm{NR}_{2}^{\prime}$ (when $\mathrm{R}=\mathrm{H}, \mathrm{Me} ; \mathrm{R}^{\prime}=\mathrm{H}$, $\mathrm{Me}, \mathrm{Et}, i$-Pr, $i$-Bu and $\mathrm{Bu}$ ) in sulfuric acid media. To the best of our knowledge, no protonation data for these series of tertiary amides (obtained by means of UV spectroscopy), have been published so far. Furthermore, it is important to investigate the correlation between protonation constants and substituents, in order to determine the influence of polar and steric effects on the basicity of investigated amides.

\section{EXPERIMENTAL}

\subsection{Materials}

All investigated amides (Table 1) were used without further purification.

Stock solutions of the aliphatic amides were prepared in deionized water. Reagent grade sulfuric acid (97\% by weight, Alkaloid - Skopje) was used. Three series of sulfuric acid were prepared: $0.0-1.0 \mathrm{~mol} \mathrm{dm}^{-3}$ with $0.1 \mathrm{~mol} \mathrm{dm}^{-3}$ increments; $0.0-10.0 \mathrm{~mol} \mathrm{dm}^{-3}$ with $0.5 \mathrm{~mol} \mathrm{dm}^{-3}$ increments; and $10.0-15.0 \mathrm{~mol} \mathrm{dm}{ }^{-3}$ with $1.0 \mathrm{~mol}$ $\mathrm{dm}^{-3}$ increments. The exact concentration of sulfuric acid was determined by titration against sodium hydroxide (Titrival, Alkaloid - Skopje). 
Ta b le 1

Abbreviations and analytical concentrations of investigated amides

\begin{tabular}{lllc}
\hline \hline Compound & Abrevation & Company & $\begin{array}{c}\boldsymbol{c} \text { (amide)/ } \\
\mathbf{1 0}^{-\mathbf{4}} \mathbf{\text { mol dm }}\end{array}$ \\
\hline Formamide & FA & Merck & 1.66 \\
$N, N$-dimethylformamide & DMFA & Merck & 0.86 \\
$N, N$-diethylformamide & DEFA & Fluka & 1.18 \\
$N, N$-diisopropylformamide & DiPFA & Fluka & 0.90 \\
$N, N$-diisobutilformamide & DiBFA & Fluka & 0.73 \\
$N, N$-dibutilformamide & DBFA & Fluka & 0.73 \\
Acetamide & AA & Fluka & 0.22 \\
$N, N$-dimethylacetamide & DMAA & Fluka & 1.15 \\
$N, N$-diethylacetamide & DEAA & Fluka & 1.22 \\
$N, N$-diisopropylacetamide & DiPAA & Aldrich & 0.98 \\
\hline \hline
\end{tabular}

\section{2. $\mathrm{p} \mathrm{K}_{\mathrm{BH}}{ }^{+}$measurements}

The concentrations of the aliphatic amides for the $\mathrm{p} K_{\mathrm{BH}}{ }^{+}$determination are given in Table 1 . The UV spectra of the substrates and appropriate blanks were recorded in a range of sulfuric acid solutions from 0.0 to $15.0 \mathrm{~mol} \mathrm{dm}{ }^{-3}$. The UV spectra were recorded immediately after preparing the solutions, on a Varian Cary 50 Spectrophotometer in $1 \mathrm{~cm}$ quartz cell, in the range from 190 to 350 $\mathrm{nm}$, with resolution of $1 \mathrm{~nm}$ at room temperature $\left(25 \pm 1^{\circ} \mathrm{C}\right)$.

\subsection{Determination of $\mathrm{p} \mathrm{BH}^{+}$}

\subsubsection{Calculation of ionization ratio}

Ionization ratios can be calculated according to the following equation:

$$
I=\frac{c\left(\mathrm{BH}^{+}\right)}{c(\mathrm{~B})}=\frac{A(\mathrm{~B})-A}{A-A\left(\mathrm{BH}^{+}\right)}
$$

where $A(\mathrm{~B})$ and $A\left(\mathrm{BH}^{+}\right)$are the absorbances at selected wavelengths (from UV or reconstructed spectra) of free and protonated base respectively.

Also, ionization ratios were calculated from mol fraction for free (B) and protonated base $\left(\mathrm{BH}^{+}\right)$using following equation:

$$
I=\frac{c\left(\mathrm{BH}^{+}\right)}{c(\mathrm{~B})}=\frac{x\left(\mathrm{BH}^{+}\right)}{x(\mathrm{~B})}
$$

Determination of the dissociation constant depends on the method used, and the wavelengths selection [14]. Therefore, equilibrium concentration of the base and the conjugated acid, i.e. their molar fractions for each sulfuric acid concentration were obtained by the method of least squares, solv- ing the system of $p$ linear equations (where $p=$ number of wavelengths in all spectral range):

$$
\begin{aligned}
& A^{\lambda_{1}}=A_{\mathrm{B}}^{\lambda_{1}} \cdot x_{\mathrm{B}}+A_{\mathrm{BH}^{+}}^{\lambda_{1}} \cdot x_{\mathrm{BH}^{+}} \\
& A^{\lambda_{2}}=A_{\mathrm{B}}^{\lambda_{2}} \cdot x_{\mathrm{B}}+A_{\mathrm{BH}^{+}}^{\lambda_{2}} \cdot x_{\mathrm{BH}^{+}} \\
& A^{\lambda_{p}}=A_{\mathrm{B}}^{\lambda_{p}} \cdot x_{\mathrm{B}}+A_{\mathrm{BH}^{+}}^{\lambda_{p}} \cdot x_{\mathrm{BH}^{+}}
\end{aligned}
$$

where $A^{\lambda p}$ are reconstructed absorbance at wavelength $p$.

\subsubsection{Determination of the protonation parameters}

In order to determine the strength of the studied weak bases, the thermodynamic $\mathrm{p}{\mathrm{BH}}^{+}$values were calculated using three different methods: the equation proposed by Yates and McClelland eq. (4) [26], the Bunnett and Olsen method - eq. (5) [27] and the excess acidity method (EAM) eq. (6) [28].

$$
\begin{gathered}
\log I=m^{\prime}\left(-H_{\mathrm{X}}\right)+\mathrm{p} K_{\mathrm{BH}^{+}} \\
\log I+H_{0}=\phi\left(H_{0}+\log \left\{c_{\mathrm{H}^{+}}\right\}\right)+\mathrm{p} K_{\mathrm{BH}^{+}} \\
\log I-\log \left\{c_{\mathrm{H}^{+}}\right\}=m^{*} \cdot X+\mathrm{p} K_{\mathrm{BH}^{+}}
\end{gathered}
$$

where $\left\{c_{\mathrm{H}}^{+}\right\}=c_{\mathrm{H}}{ }^{+} /\left(\mathrm{mol} \mathrm{dm}{ }^{-3}\right), H_{0}$ is Hamett's acidity function, $H_{\mathrm{X}}=H_{\mathrm{A}}$ is its corrected value for amides, and $X$ is the excess acidity function. The values of $\log \left\{c_{\mathrm{H}}{ }^{+}\right\}$and $X$ are available for aqueous $\mathrm{H}_{2} \mathrm{SO}_{4}$ [29]. The data for $H_{0}$ are calculated using the equations (7) [20]: 


$$
-H_{0}=X+\log \left\{c_{\mathrm{H}^{+}}\right\}
$$

The amide function in the literature can be found in different ways in its determination. Usually this is done by equation (8):

$$
-H_{A}=m^{*} \cdot X+\log \left\{c_{\mathrm{H}^{+}}\right\}
$$

where $m^{*}$ is value for each compound [28], or the average value of observed compounds [10]. Due to the inability to determine the solvation parameters with EAM for some of the amides investigated, we used equation (8) for all compounds, where for $m^{*}$ the value of 0.6 was taken. The $m^{*}$ value depends on both polar and steric effect of the substituents and the substitution site, and increases enlarging the alkyl substituent bonded to a carbonyl group [16]. Unfortunately, there are no analogue data for $\mathrm{N}$-substitution at aliphatic amides. The value of 0.6 is taken as average of the $m^{*}$ values determined by NMR technique (0.43 for FA [16], 0.67 [16] and 0.64 [20] for DMFA, 0.55 for AA [21], 0.62 for DMAA [20] and 0.84 for DEAA [21]).

\section{RESULTS AND DISCUSSION}

Ten aliphatic amides, mostly tertiary, i.e. $N, N$-dialkyl substituted formamides and acetamides were selected for investigation of the protonation reaction. The increasing of the environment acidity induces changes in the spectra of the aliphatic amides, as a result of the protonation reaction and medium effect. The spectra of the investigated formamides and acetamides are characterized by one wide absorption band resulting from $\pi \rightarrow \pi^{*}$ transition. Concerning the primary amides, this band is in the 190-210 $\mathrm{nm}$ region, while at tertiary amides this band appears in a somewhat wider region (190-230 nm).

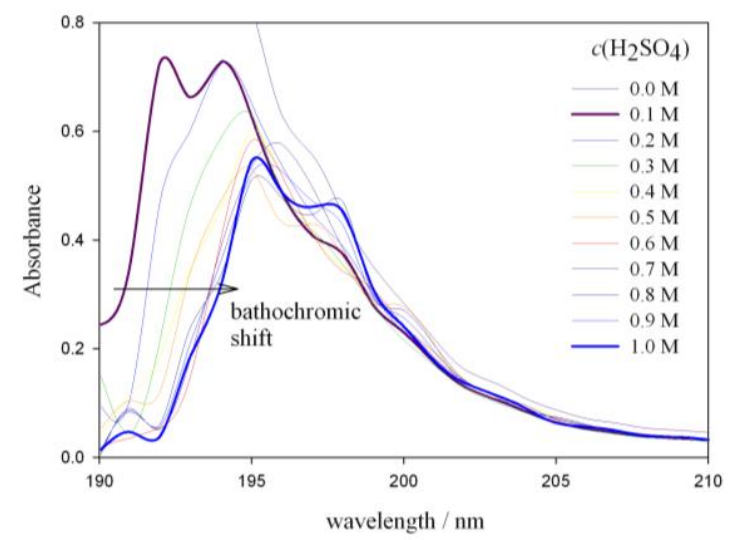

Fig. 1. Bathochromic shift in UV spectra of FA in $0.0-1.0 \mathrm{~mol} \mathrm{dm}^{-3} \mathrm{H}_{2} \mathrm{SO}_{4}$
By changing the sulfuric acid concentration in the region $0.0-1.0 \mathrm{~mol} \mathrm{dm}^{-3}$, the presence of bathochromic and hypochromic effect are evident in the spectra of FA (Figure 1, same effect is observed in AA). The further increasing of the media

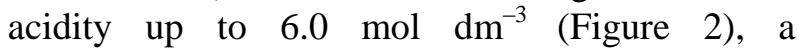
hypsochromic and hyperchromic shift of the absorption band is observed. Furthermore, in the sulfuric acid concentration range from 7.0 to $15.0 \mathrm{~mol}$ $\mathrm{dm}^{-3}$, the absorption band maximum is observed under $190 \mathrm{~nm}$. Unlike primary amides, with the increasing acidity, all $N, N$-disubstituted formamides exhibit only hypsochromic effect.

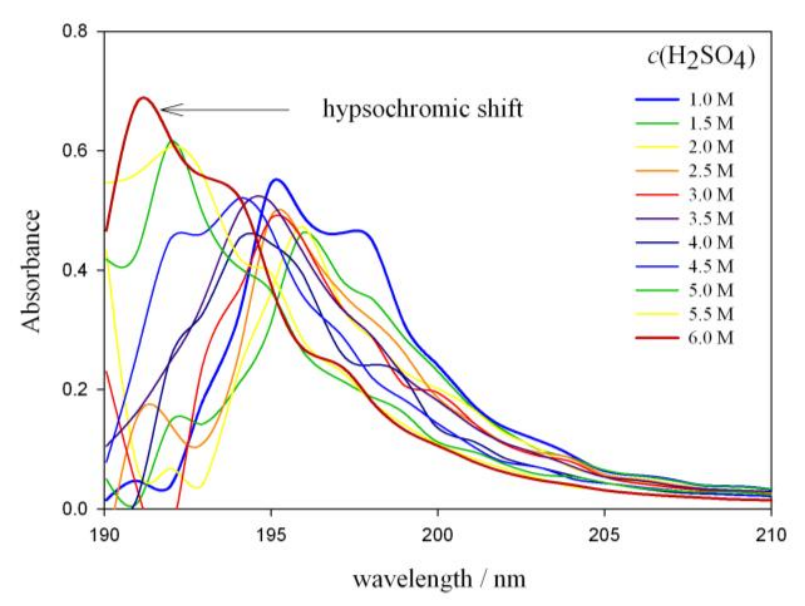

Fig. 2. UV spectra of FA in $1.0-6.0 \mathrm{~mol} \mathrm{dm}^{-3} \mathrm{H}_{2} \mathrm{SO}_{4}$

The experimental transitions for free and protonated base in UV spectra of all investigated amides are presented in Table 2. It may be noted that the alkyl substitution on the $N$-atom in the molecule the FA, indices bathochromic shift (for about $2-3 \mathrm{~nm}$ ) of the absorption peaks in the spectra of the substituted formamide. The same effect is observed in the absorption spectra of alkylmethylketones, $\mathrm{RC}(\mathrm{O}) \mathrm{Me}$, by increasing the alkyl series $(\mathrm{R}=\mathrm{Me}$, Et, $n$-Pr, $i$-Pr, $t$-Bu) [30].

Inability to determine the maximum absorbance of FA and AA in water, that is due to their high absorption, results in shoulder appearance in their UV spectra (Table 2), which is not the case at tertiary analogues. The observed difference between UV spectra of FA and AA in water, on one side and corresponding UV spectra of tertiary amides on the other, is quite probably due to intermolecular amide-water and possibly amide-amide hydrogen bonds. The former are more likely to appear in primary [31] than in tertiary amides, while the latter appear only in primary amides. 
Table 2

Experimental transitions in the UV spectra of amides

\begin{tabular}{lcccc}
\hline \hline \multirow{2}{*}{ Compound } & \multicolumn{2}{c}{ Unprotonated form $\mathbf{B}$} & \multicolumn{2}{c}{ Protonated form $\mathbf{B H}^{+}$} \\
\cline { 2 - 5 } & $\lambda_{\max } / \mathrm{nm}$ & $\log \varepsilon^{\mathrm{a}}$ & $\lambda_{\max } / \mathrm{nm}$ & $\log \varepsilon^{\mathrm{a}}$ \\
\hline FA & $197(\mathrm{sh})$ & 3.52 & $190^{\mathrm{b}}$ & 3.26 \\
DMFA & 197 & 4.05 & $190^{\mathrm{b}}$ & 4.01 \\
DEFA & 199 & 3.96 & $190^{\mathrm{b}}$ & 3.92 \\
DiPFA & 200 & 4.00 & 191 & 3.90 \\
DiBFA & 202 & 3.98 & 194 & 3.90 \\
DBFA & 200 & 4.03 & 192 & 3.97 \\
AA & $197(\mathrm{sh})$ & 4.27 & $190^{\mathrm{b}}$ & 4.01 \\
DMAA & 196 & 4.00 & $190^{\mathrm{b}}$ & 3.88 \\
DEAA & 199 & 3.97 & $190^{\mathrm{b}}$ & 3.95 \\
DiPAA & 201 & 4.07 & 193 & $4.09^{\mathrm{c}}$ \\
\hline \hline
\end{tabular}

${ }^{\mathrm{a}} \log \varepsilon=\log \left\{\varepsilon / \mathrm{mol}^{-1} \mathrm{dm}^{3} \mathrm{~cm}^{-1}\right\}$ for free $(\mathrm{B})$ and protonated base $\left(\mathrm{BH}^{+}\right)$determined in sulfuric acid solutions with concentration 0.5 and $15.0 \mathrm{~mol} \mathrm{dm}^{-3}$, respectively.

${ }^{\mathrm{b}}$ Maximum absorbance of protonated form appears under $190 \mathrm{~nm}$.

${ }^{\mathrm{c}} \log \varepsilon$ is calculated from spectra at acidity of $8 \mathrm{~mol} \mathrm{dm}^{-3}$.

\subsection{Determination of the $\mathrm{pK}_{\mathrm{BH}}{ }^{+}$}

It is well known that when the protonation reaction occurs in a relatively weak acidic environment, the medium effect is more pronounced for $\mathrm{BH}^{+}$than for $\mathrm{B}$ [32]. This is exactly the case in aliphatic amides. Thus, by increasing the acidity, the shift of the absorption band becomes more expressed. For the ionization ratios calculation with eq. (1) the standard approach is to select the wavelength of maximum absorption (of the form $\mathrm{B}$ or $\mathrm{BH}^{+}$). In our case, this is impossible due to the existing heavy overlap of spectral curves around $\lambda_{\max }$ of form $\mathrm{B}$ (the $\lambda_{\max }$ of $\mathrm{BH}^{+}$cannot be estimated). The selection of wavelength and acidity range for ionization ratios determination was performed for each of the studied compounds. Thus, for FA (Figure 3 ) and AA, the acidity region $0.0-1.0 \mathrm{~mol} \mathrm{dm}^{-3}$ $\mathrm{H}_{2} \mathrm{SO}_{4}$ (with increment of $0.1 \mathrm{~mol} \mathrm{dm}$ ) is not applicable, due to the previously mentioned bathochromic effect of the absorption band. On the other hand, concerning other compounds, i.e. DiPFA and DiPAA (Fig. 3), it was necessary to include the acidity region mentioned above. The dependence of absorbances from the concentration of sulfuric acid at selected wavelengths shows that the protonation of aliphatic amides, especially acetamides, is already going on at low acidity. Therefore, the obtained protonation curve is not shaped as the typical "S" curve.

Generally speaking, the presence of clearly defined absorption bands of the protonated and unprotonated base in the spectra is the necessary condition for successful CVA application. In this study, the CVA applied for medium effect removing has not given the expected results, as it was successfully done in substituted benzamides [10] and toluidides [11]. The reason for this is that the absorption bands of $\mathrm{BH}^{+}$for the spectra recorded in sulfuric acid at concentrations higher than $6 \mathrm{~mol}$ $\mathrm{dm}^{-3}$ are present under $190 \mathrm{~nm}$. Therefore, the obtained reconstructed spectra are not monotonous, i.e. absorbance at selected wavelength does not change proportionately with the change of sulfuric acid concentration. As an example, the reconstructed spectra of FA (with and without spectra in water) are presented in Supplementary data. Similar results were obtained for all amides with exception of AA, DMAA and DiPAA. Therefore, the calculation of ionization ratios was performed through the absorbance at selected wavelengths from the original UV spectra (see Supplementary data - pK tables).

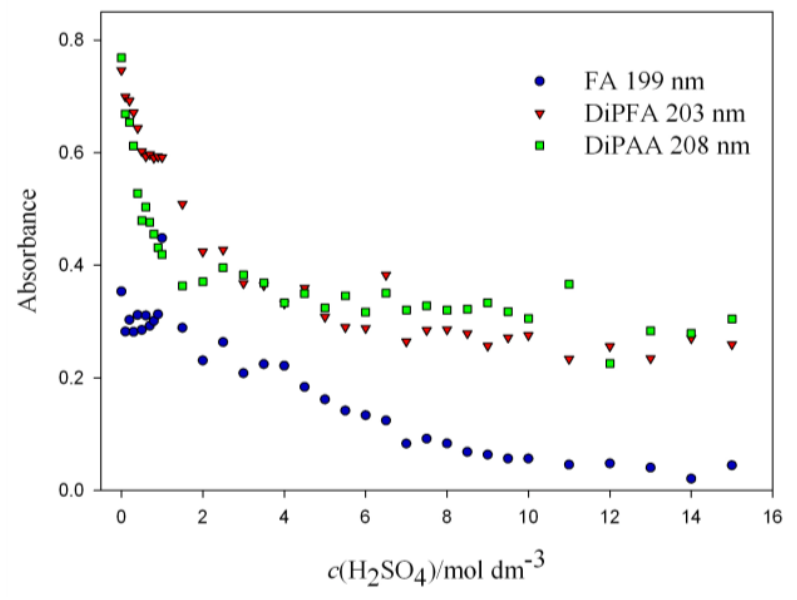

Fig. 3. $A(\lambda)$ as a function of $c\left(\mathrm{H}_{2} \mathrm{SO}_{4}\right)$ for some amides

In the exceptions mentioned above, besides the experimental absorbances, an attempt was made to calculate the ionization ratios through other means. Thus, in the case of AA we used absorbances differences at small absorption peaks at 
196, 198 and $201 \mathrm{~nm}$ from the UV spectra, and 196 and $201 \mathrm{~nm}$ from the reconstructed spectra of AA. In the case of DMAA, we used the convenient way through absorbances at selected wavelengths, but from their reconstructed spectra. Figure 4 presents the reconstructed (with two characteristic vectors) spectra of DMAA in the spectral range of 190-220 $\mathrm{nm}$ in $0.0-9.0 \mathrm{~mol} \mathrm{dm}^{-3}$ sulfuric acid. While, in the case of DiPAA ionization ratios, these were calculated by molar fractions on unprotonated and protonated form (Fig. 5), method that was previously applied with success for toluidides [11]. Similarly, in our previous investigation for indoles, the same approach was used, with the exception that the calculations are based on the absorbances used at four selected wavelengths [33].

The wavelengths for $\mathrm{p} K_{\mathrm{BH}}{ }^{+}$calculation were selected after detailed statistical analysis, regarding the following criteria: the highest correlation coefficient for the selected acidity area, taking into account that $\log I$ should roughly be in the range of values from -1 to 1 .

The average $\mathrm{p} K_{\mathrm{BH}}{ }^{+}$values obtained from the calculation for several different wavelengths (or by another approach mentioned above), in different acidity regions, employing three methods (YMCM, EAM and BOM) are presented in Table 3. All $\mathrm{p} K_{\mathrm{BH}}{ }^{+}$values were calculated using least squares linear regression. The correlation coefficients were, as a rule, in the range $0.950<r<0.995$, with few exceptions for some acetamides (see Supplementary data).

Investigating the data obtained using YMCM method (Table 3 ), we can conclude that the acidity function $H_{\mathrm{A}}$ does not adequately describe protonation equilibria, because the $m^{\prime}$ slope is not equal to
1. An exception to this is DiPAA which is protonated at lower sulfuric acid concentrations.

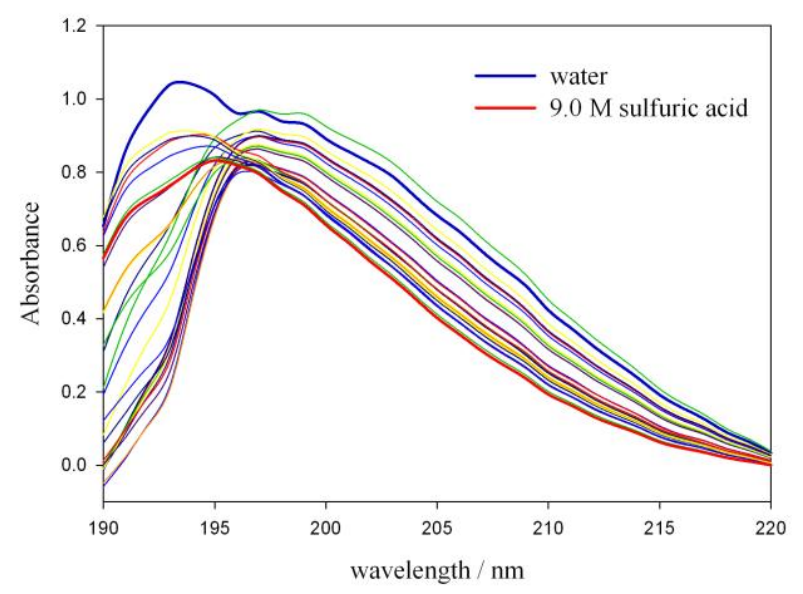

Fig. 4. Reconstructed spectra of DMAA with two characteristic vector

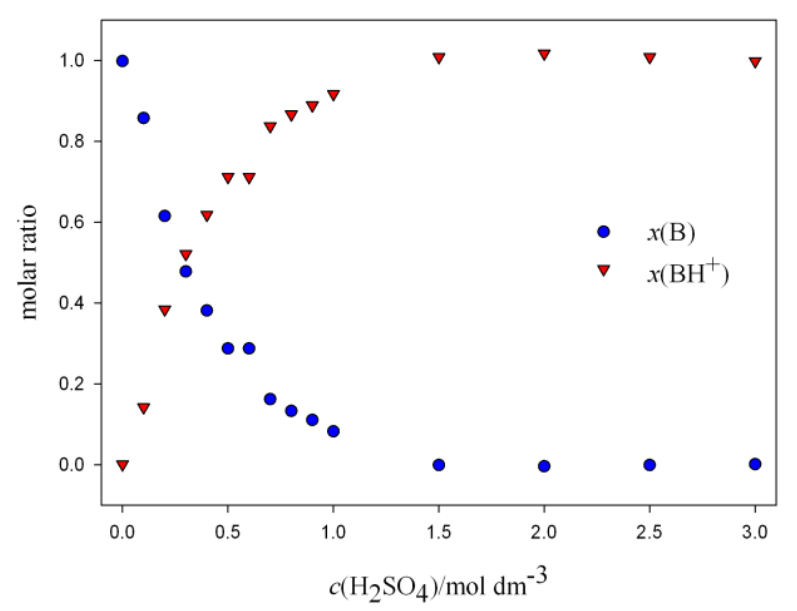

Fig. 5. Molar fractions of unprotonated and protonated forms of DiPAA as a function of $c\left(\mathrm{H}_{2} \mathrm{SO}_{4}\right)$

Table 3

Protonation parameters for investigated amides

\begin{tabular}{|c|c|c|c|c|c|c|}
\hline \multirow{2}{*}{ Compound } & \multicolumn{2}{|c|}{ YMCM $\left(H_{\mathrm{A}}\right)$} & \multicolumn{2}{|c|}{ EAM } & \multicolumn{2}{|c|}{ BOM } \\
\hline & $\mathrm{p} K_{\mathrm{BH}}{ }^{+}$ & $m^{\prime}$ & $\mathrm{p} K_{\mathrm{BH}}^{+}$ & $m^{*}$ & $\mathrm{p} K_{\mathrm{BH}}{ }^{+}$ & $\phi$ \\
\hline $\mathbf{F A}$ & $-1.19 \pm 0.26^{\mathrm{a}}$ & $0.62 \pm 0.10$ & $-\mathbf{1 . 4 3} \pm 0.09$ & $0.35 \pm 0.02$ & $-\mathbf{1 . 4 4} \pm 0.08$ & $0.65 \pm 0.02$ \\
\hline DMFA & $-\mathbf{0 . 9 3} \pm 0.13$ & $0.59 \pm 0.06$ & $-\mathbf{1 . 1 5} \pm 0.10$ & $0.29 \pm 0.03$ & $-\mathbf{1 . 1 5} \pm 0.11$ & $0.72 \pm 0.04$ \\
\hline DEFA & $-\mathbf{0 . 8 1} \pm 0.04$ & $0.65 \pm 0.06$ & $-\mathbf{0 . 8 4} \pm 0.08$ & $0.23 \pm 0.03$ & $-\mathbf{0 . 8 0} \pm 0.03$ & $0.77 \pm 0.05$ \\
\hline DiPFA & $-\mathbf{0 . 3 3} \pm 0.03$ & $0.80 \pm 0.05$ & $-\mathbf{0 . 3 1} \pm 0.03$ & $0.38 \pm 0.07$ & $-\mathbf{0 . 3 2} \pm 0.04$ & $0.62 \pm 0.04$ \\
\hline DiBFA & $-\mathbf{1 . 0 8} \pm 0.09$ & $0.72 \pm 0.05$ & $-\mathbf{1 . 1 7} \pm 0.10$ & $0.34 \pm 0.10$ & $-\mathbf{1 . 1 3} \pm 0.04$ & $0.68 \pm 0.06$ \\
\hline DBFA & $-\mathbf{0 . 6 7} \pm 0.03$ & $0.67 \pm 0.14$ & $-\mathbf{0 . 7 8} \pm 0.05$ & $0.44 \pm 0.07$ & $-\mathbf{0 . 8 0} \pm 0.05$ & $0.56 \pm 0.04$ \\
\hline $\mathbf{A A}$ & $-\mathbf{0 . 3 9} \pm 0.14$ & $0.49 \pm 0.08$ & $-\mathbf{0 . 6 5} \pm 0.07$ & $0.19 \pm 0.05$ & $-\mathbf{0 . 5 7} \pm 0.05$ & $0.87 \pm 0.02$ \\
\hline DMAA & $-\mathbf{0 . 2 8} \pm 0.05$ & $0.48 \pm 0.16$ & -0.28 & - & $-\mathbf{0 . 2 9} \pm 0.05$ & $0.93 \pm 0.12$ \\
\hline DEAA & $-\mathbf{0 . 3 4} \pm 0.04$ & $0.75 \pm 0.24$ & -0.35 & - & $-\mathbf{0 . 3 2} \pm 0.02$ & $0.82 \pm 0.23$ \\
\hline DiPAA & $\mathbf{0 . 3 5} \pm 0.05$ & $1.07 \pm 0.09$ & $\mathbf{0 . 3 8} \pm 0.06$ & - & $\mathbf{0 . 3 6} \pm 0.15$ & - \\
\hline
\end{tabular}

${ }^{\mathrm{a}}$ Confidence limits for average values 
In comparison with the results obtained from other authors which have successfully employed EAM with NMR technique [16, 21], in this work, the application of EAM on some of the compounds investigated (Table 3) gave results with a low correlation coefficient. This, to some extent, an unexpected outcome, accounting only for acetamides, which are stronger bases and readily protonated at lower acidity. Accordingly, it was not possible to obtain relevant values for the solvation parameter $m^{*}$. One of the possible explanations for these results might be the instrumental technique applied. Namely, the instrument response is very low and probably more influenced by experimental errors than the NMR.

Unlike the above-mentioned weak behavior of the studied acetamides, the results for $\mathrm{p} \mathrm{KHH}^{+}$ values for FA, obtained with EAM and BOM, are in good agreement with the ones determined by other authors. Thus, the values obtained in this study are in accordance with the value of -1.47 , calculated by Bagno et al. [16]. At the same time, they differ from the $\mathrm{p} K_{\mathrm{BH}}{ }^{+}$values obtained from Liler [17], estimated at $-2.0 \pm 0.15$, through the half-protonation values $\left(H_{\mathrm{A}}^{1 / 2}\right)$.

The $\mathrm{p}{\mathrm{BH}^{+}}^{+}$value of -1.13 for DMFA coincides with that given by Bagno and Scorrano [20], and is close to the value of -1.2 from Grant and coworkers [23]. However, the $\mathrm{p} K_{\mathrm{BH}}{ }^{+}$value for DMFA differs from the value of -1.33 , which is published by Liler [17]. From the same source, the $\mathrm{p} K_{\mathrm{BH}}{ }^{+}$values for DEFA and DiPFA were -1.23 and -1.2 , respectively, which differ from the values obtained in this work. It is obvious that the results of Liler [17] deviate from the (now accepted as corrected) values of FA and DMFA, for $\sim 0.6$ and $\sim 0.2 \mathrm{pK}$ units, respectively. However, for DEFA and DiPFA, we could not derive the same conclusion, since the results obtained in this work are the only known ones.

The results for AA obtained with EAM $(-0.65)$ and BOM $(-0.57)$ differ from each other, although the first one is closer to the data available in the literature of -0.66 [16] and -0.73 [21], determined by applying the same method. On the other hand, our value obtained by BOM is close to the value of -0.62 , which was determined by the conductometric method [23]. Values for DMA $(-0.29)$ do not comply with some literature data $(-0.21)[16,20]$, but are practically equal to the value of -0.28 obtained by Grant et al. [23].

Apart from this, the calculated $\mathrm{p} K_{\mathrm{BH}}{ }^{+}$value for DEAA is close to -0.33 , as published previously [21]. The value obtained for DiPAA is rather unexpected, since it is positive $(+0.35)$; unfortunately, there were no available literature data sources for comparison. If one is analyzing the values obtained for $N, N$-dialkyl substituted benzamides [21] in comparison with the corresponding acetamide analogues, the calculated $\mathrm{p} K_{\mathrm{BH}}{ }^{+}$value for DiPAA is more acceptable. Namely, the differences in $\mathrm{p} K$ values of acetamide and benzamide, and between their dimethyl and diethyl analogues, which range from 0.71 to 0.97 , is close to 0.9 , as was in the case for the isopropyl group (Table 4).

T a ble 4

Comparison of $\mathrm{p} \mathrm{K}_{\mathrm{BH}}{ }^{+}$of $\mathrm{N}, \mathrm{N}$-dialkyl substituted benzamides and acetamides

\begin{tabular}{lccc}
\hline \hline R & Benzamides & Acetamides & Diference \\
\hline & & $-0.73^{\mathrm{a}}$ & 0.81 \\
$\mathrm{H}$ & $-1.54^{\mathrm{a}}$ & $-0.65^{\mathrm{b}}$ & 0.89 \\
& & $-0.57^{\mathrm{c}}$ & 0.97 \\
$\mathrm{Me}$ & $-1.00^{\mathrm{a}}$ & $-0.29^{\mathrm{c}}$ & 0.71 \\
$\mathrm{Et}$ & $-1.14^{\mathrm{a}}$ & $-0.32^{\mathrm{c}}$ & 0.81 \\
$\mathrm{Pr}$ & $-0.55^{\mathrm{a}}$ & $+0.36^{\mathrm{c}}$ & 0.91 \\
\hline \hline
\end{tabular}

${ }^{\mathrm{a}}$ Ref. [21], ${ }^{\mathrm{b}}$ this work by EAM, ${ }^{\mathrm{c}}$ this work by BOM

\subsection{Hammett-Taft correlations}

Hammett's correlation [34] connects the changes in the dissociation constants of any reaction with $\sigma$-constants of the substituents (obtained empirically) and the reaction constant $\rho$ :

$$
\log K-\log K_{0}=\rho \cdot \sigma .
$$

However, this equation is practically inapplicable for aliphatic compounds, because of the significant contribution of the steric effect along with the polar one. Usually, the combined contribution of both effects is expressed by Taft's [35] equation:

$$
\log K-\log K_{0}=\rho^{*} \cdot \sigma^{*}+\delta \cdot E_{s},
$$

where $\rho^{*}$ and $\delta$ are reaction constants, and $\sigma^{*}$ is constant that accounts for the polar effect of the substituents, while $E_{\mathrm{s}}$ is steric constant.

Both polar and steric effect have cumulative property, thus in both equations, (9) and (10), instead of individual values for $\sigma^{*}$ and $E_{\mathrm{s}}$, their cumulative values $\Sigma \sigma^{*}$ and $\Sigma E_{\mathrm{s}}$ could be substituted. Graphically, the dependence of $\mathrm{p} \mathrm{BH}_{\mathrm{BH}}{ }^{+}$values from $\Sigma \sigma^{*}$ and $\Sigma E_{\mathrm{s}}$ is presented on Figure 6.

The values used for $\sigma^{*}$ and $E_{\mathrm{s}}$ are obtained empirically, and represent the results from the investigations conducted by Taft [35] and Hancock et al. [36]. The inspection of the figures reveals 
that the $\mathrm{p} \mathrm{K}_{\mathrm{BH}}{ }^{+}$values are uniquely influenced by neither $\Sigma \sigma^{*}$ nor $\Sigma E_{\mathrm{s}}$. By applying Hammett's equation on the formamides and acetamides investigated, no satisfactory correlation was obtained in any possible combination of Taft's constants. This is an

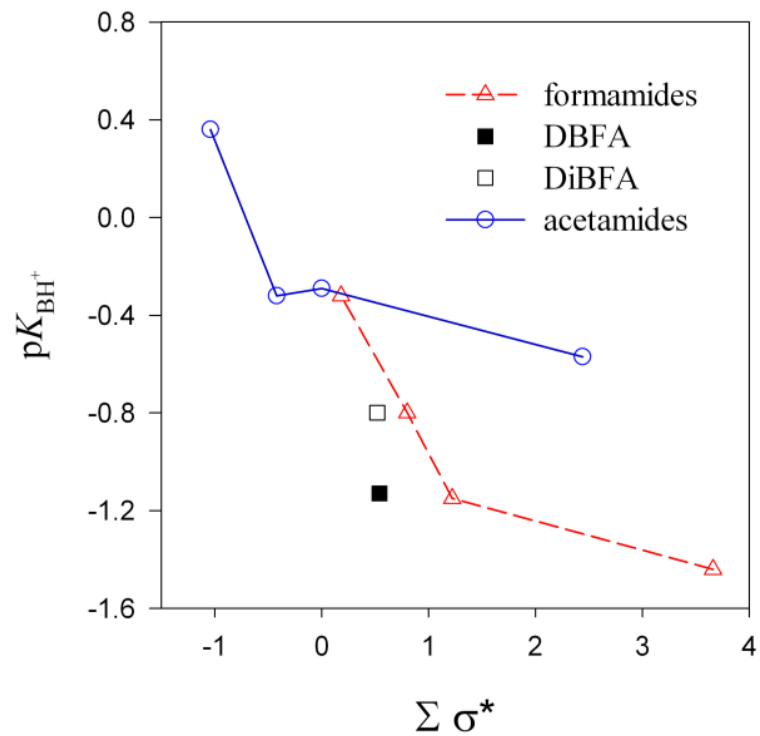

(a) analogous conclusion to that formulated by Bagno et al. [16]. However, there are evident similarities in the influence of the substituents, either by polar or steric effects, on the protonation constants for both series of substances (formamides and acetamides).

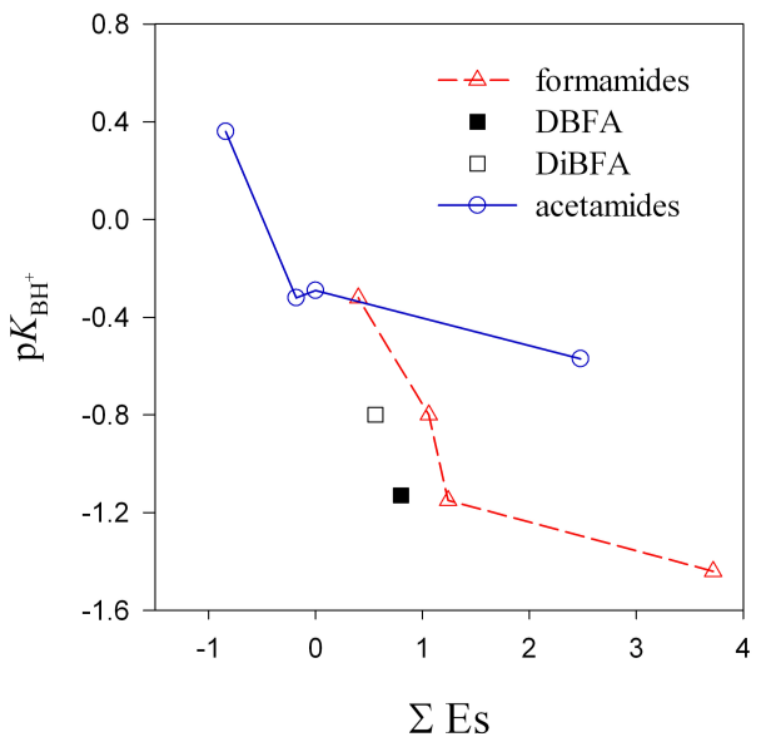

(b)

Fig. 6. Dependence of $\mathrm{p}{K_{\mathrm{BH}}}^{+}$values of aliphatic amides on: (a) $\Sigma \sigma^{*}$ and (b) $\Sigma E_{\mathrm{s}}$

To illustrate and confirm the above discussion, the equations representing the best correlation of $\mathrm{p}{K_{\mathrm{BH}}}^{+}$values for DMFA, DEFA and DiPFA, on $\Sigma \sigma^{*}$, i.e. $\Sigma E_{\mathrm{s}}$, plotted in Figure 6, are listed below (eq. (11) and eq. (12)). This conclusion is in accordance with Liler's results [17], i.e. the basicity of $N, N$-disubstituted formamides increases linearly with the inductive effect of the electron donating groups in order: methyl < ethyl < isopropyl.

$$
\begin{gathered}
\Delta \mathrm{p} K_{\mathrm{BH}}{ }^{+}(\mathrm{BOM})=-0.80 \pm 0.02 \cdot \Sigma \sigma^{*}+0.98 \pm 0.01 \\
r=0.9998, s=0.01, n=3
\end{gathered}
$$

$$
\begin{gathered}
\Delta \mathrm{p} K_{\mathrm{BH}}{ }^{+}(\mathrm{BOM})=-0.92 \pm 0.21 \cdot \Sigma E_{\mathrm{s}}+1.22 \pm 0.21 \\
r=0.9740, s=0.13, n=3
\end{gathered}
$$

In both equations, the intercept values indicate the influence of another effect present (apart from that used in the correlation). In order to analyze the contribution of both effects, eq. (10) was applied and the calculated reaction constants are presented in Table 5. From this approach, it can be concluded that the polar effect slightly dominates over the steric one, both for the protonation of formamides and acetamides.

Table 5

Taft's correlations of $\Delta \mathrm{p} K_{\mathrm{BH}}{ }^{+}$(calculated with BOM)

\begin{tabular}{lccccc}
\hline \hline Compounds & Constants & $\boldsymbol{\rho}^{*}, \boldsymbol{\delta}$ & $\boldsymbol{r}$ & $\boldsymbol{s}$ & $\boldsymbol{n}$ \\
\hline Formamides & $\Sigma \sigma^{*}, \Sigma E_{\mathrm{s}}$ & $-1.90,1.80$ & 0.6430 & 0.32 & 6 \\
Formamides without & $\Sigma \sigma^{*}, \Sigma E_{\mathrm{s}}$ & $-2.77,2.64$ & 0.8988 & 0.26 & 4 \\
DiBFA and DBFA & $\Sigma \sigma^{*}, \Sigma E_{\mathrm{s}}$ & $-0.94,0.78$ & 0.7733 & 0.31 & 4 \\
Acetamides &
\end{tabular}

$\sigma, E_{\mathrm{s}}-$ substituent constants; $\rho *, \delta$ - reaction constants;

$r$-correlation coefficient; $s$-standard error; $n$-number of compound

\subsection{Structure-solvation correlations}

Different $m^{*}$ values for the amides studied indicate that a variety of compound-solvent interactions exist. From the results presented in Table 3, it can be clearly concluded that it is not possible to expect satisfactory correlation between $K_{\mathrm{BH}}{ }^{+}$values and solvation parameters. Exceptions to this are the first three formamides (FA, DMFA and DEFA), 
whereas the excellent correlation between $\mathrm{p} K_{\mathrm{BH}}{ }^{+}$ and $m *$ is presented with eq. (13):

$$
\begin{gathered}
\mathrm{p} K_{\mathrm{BH}}{ }^{+}(\mathrm{EAM})=-4.92 \pm 0.14 \cdot m^{*}+0.29 \pm 0.04 \\
r=0.9996, s=0.01, n=3
\end{gathered}
$$

Furthermore, the correlations obtained between the solvation parameter and separately with $\Sigma \sigma^{*}$ and $\Sigma E_{\mathrm{s}}$, presented with eq. (14) and (15), indicate that $m^{*}$ approximately is equally dependent from the both factors: substituent polar and steric effect. The substituent increasing in the order: $\mathrm{H}<$ $\mathrm{Me}<\mathrm{Et}$, leads to a decrease of $\Sigma \sigma^{*}$ and $\Sigma E_{\mathrm{s}}$ values. At the same time, according to eq. (14) and (15), the $m^{*}$ value is also decreasing, indicating increased solvation of the protonated base. Finally, it results in protonation going on in more diluted sulfuric acid solutions.

$$
\begin{gathered}
m^{*}=0.17 \pm 0.02 \cdot \Sigma \sigma^{*}+0.10 \pm 0.02 \\
r=0.9954, s=0.01, n=3 \\
m^{*}=0.20 \pm 0.04 \cdot \Sigma E_{\mathrm{s}}+0.03 \pm 0.06 \\
r=0.9769, s=0.02, n=3
\end{gathered}
$$

\subsection{Correlations of $\mathrm{p} K_{\mathrm{BH}}{ }^{+}$with $c\left(\mathrm{H}_{2} \mathrm{SO}_{4}\right)$ at half and full protonation}

Estimates for $c\left(\mathrm{H}_{2} \mathrm{SO}_{4}\right)$ of half-protonation $\left(c_{\mathrm{p}^{1 / 2}}\right)$ are made by $\log I \approx 0$, while the $c\left(\mathrm{H}_{2} \mathrm{SO}_{4}\right)$ for completed protonation $\left(c_{\mathrm{p}}\right)$ is estimated by the largest $\log I$ value.

Table 6

Correlations of $\mathrm{p} \mathrm{K}_{\mathrm{BH}}{ }^{+}$calculated with $\mathrm{BOM}$ with $\mathrm{c}\left(\mathrm{H}_{2} \mathrm{SO}_{4}\right)$ at half and full protonation

\begin{tabular}{lcccccc}
\hline \hline \multirow{2}{*}{$\mathbf{p} \boldsymbol{K}_{\mathbf{B H}}{ }^{+}(\mathbf{B O M})$} & \multicolumn{7}{c}{$\mathbf{p} \boldsymbol{K}_{\mathbf{B H}}{ }^{+}=(\mathbf{a} \pm \boldsymbol{s}) \cdot \boldsymbol{c}_{\boldsymbol{i}}+\mathbf{b} \pm \boldsymbol{s}$} \\
\cline { 2 - 7 } & $\boldsymbol{c}_{\mathbf{i}}$ & $\mathbf{a}$ & $\mathbf{b}$ & $\boldsymbol{r}$ & $\boldsymbol{s}$ & $\boldsymbol{n}$ \\
\hline All amides & $c_{\mathrm{p} 1 / 2}$ & $-0.31 \pm 0.04$ & $0.12 \pm 0.11$ & 0.9425 & 0.19 & 10 \\
Formamides & $c_{\mathrm{p} 1 / 2}$ & $-0.26 \pm 0.04$ & $-0.05 \pm 0.13$ & 0.9625 & 0.12 & 6 \\
Acetamides & $c_{\mathrm{p}} / 2$ & $-0.69 \pm 0.23$ & $0.55 \pm 0.27$ & 0.9057 & 0.21 & 4 \\
All amides & $c_{\mathrm{p}}$ & $-0.12 \pm 0.04$ & $0.48 \pm 0.26$ & 0.8553 & 0.29 & 10 \\
Formamides & $c_{\mathrm{p}}$ & $-0.14 \pm 0.02$ & $0.61 \pm 0.20$ & 0.9699 & 0.11 & 6 \\
Acetamides & $c_{\mathrm{p}}$ & $-0.07 \pm 0.03$ & $0.30 \pm 0.29$ & 0.8175 & 0.28 & 4 \\
\hline \hline
\end{tabular}

$r$ - correlation coefficient, $s$ - standard error, $n$ - number of compound,

$c_{\mathrm{p}^{1 / 2}}-$ concentration of sulfuric acid at half protonation of amide,

$c_{\mathrm{p}}-$ concentration of sulfuric acid at completely protonation of amides.

Better correlation was obtained for formamide, which is not very surprising given the difficulties in determining the $\mathrm{p}{\mathrm{BH}^{+}}^{+}$of acetamide (Table 6). The significant standard errors indicate that the equations obtained could not be used to determine the $\mathrm{p} \mathrm{K}_{\mathrm{BH}}{ }^{+}$values. This was not the ultimate goal, but the idea was to show, however, that there is a protonation pattern. More precisely speaking, the stronger bases are protonated in more diluted solutions of sulfuric acid, and consequently, weak bases are protonated in more concentrated solutions of sulfuric acid. The latter is something that should ultimately be expected, but nevertheless it is not always the case [16].

\section{CONCLUSION}

UV spectroscopy was employed for the determination of $\mathrm{p} \mathrm{K}_{\mathrm{BH}}{ }^{+}$values for the whole series of tertiary aliphatic amides. The dissociation constants, as well as the solvation parameters, were calculated using three methods (Yates and McClel- land, Excess acidity and Bunnett-Olsen's method). From the results, it can be concluded that the BOM is the most suitable method, especially for acetamides where EAM cannot be applied. Estimated $\mathrm{p} K_{\mathrm{BH}}{ }^{+}$values coincide with those obtained by the more recent literature data obtained by NMR. Applying the Hammett's equation on the formamides and acetamides investigated, evident similarities in the influence of the substituents, either by polar or steric effect, on the protonation constants for both series (formamides and acetamides) are noticed. The basicity of $N, N$ disubstituted formamides increases linearly with the inductive effect of the electron donating groups in the order: methyl < ethyl < isopropyl. From Taft's approach, it can be concluded that the polar effect insignificantly dominates the steric one. Regarding the structure-solvation correlations, it can be clearly concluded that it was not possible to expect satisfactory correlation between the $\mathrm{pK}_{\mathrm{BH}}{ }^{+}$ values and the solvation parameters. Excellent correlation between $\mathrm{pK}_{\mathrm{BH}}^{+}$and $m^{*}$ was achieved for 
formamide, dimethylformamide and diethylformamide. At half and full protonation, better correlation was obtained for formamides, relative to acetamides.

\section{REFERENCES}

[1] R. F. Cookson, The determination of acidity constants, Chem. Rev., 74, 5-28 (1974).

[2] A. Arcelli, G. Porzi, S. Rinaldi, S. Sandri, An efficient acid hydrolysis of the ether bond assisted by the neighbouring benzamide group. Part 3, J. Chem. Soc. Perkin Trans. 2, 296-301 (2001).

[3] R. A. Cox, The mechanisms of the hydrolyses of $N$ nitrobenzenesulfonamides, $N$-nitrobenzamides and some other $N$-nitro amides in aqueous sulfuric acid, J. Chem. Soc. Perkin Trans. 2, 1743-1750 (1997).

[4] D. A. Marković, The hydrolysis of acrylamide and methacrylamide in aqueous sulphuric acid. I. The rate constants and the position of protonation, $J$. Serb. Chem. Soc., 59, 943-948 (1994).

[5] G. M. Loudon, M. R. Almond, J. N. Jacob, Mechanism of hydrolysis of $N$-(1-aminoalkyl) amides, $J$. Am. Chem. Soc., 103, 4508-4515 (1981).

[6] J. T. Edward, S. C. Wong, Ionization of carbonyl compounds in sulfuric acid. Correction for medium effects by characteristic vector analysis, $J$. Am. Chem. Soc., 99, 4229-4232 (1977).

[7] G. Stojković, B. Andonovski, UV study of the protonation of benzamide and $\mathrm{N}$-phenyl benzamide in sulfuric acid media, Proceedings of the 3rd Aegan Analytical Chemistry Days, Polihnitos, Lesvos, Greece, 2002, pp. 498-501.

[8] B. Garcia, R. M. Casado, J. Castillo, S. Ibeas, I. Domingo and J. M. Leal, Acidity constants of benzamide and some ortho-substituted derivatives, J. Phys. Org. Chem., 6, 101-106 (1993).

[9] R. I. Zalewski, Adaptation of characteristic vector analysis and titration curve analysis for calculations of $\mathrm{p} K_{\mathrm{BH}}{ }^{+}$from ultraviolet-visible spectral data, $J$. Chem. Soc. Perkin Trans. II, 1637-1639 (1979).

[10] G. Stojković, E. Popovski, Determination and structural correlation of $\mathrm{p} \mathrm{BH}^{+}$for meta- and parasubstituted benzamides in sulfuric acid solutions, J. Serb. Chem. Soc. 71(10), 1061-1071 (2006).

[11] G. Stojković, F. Anastasova, Protonation acidity constants for benzotoluidides in sulfuric acid solutions, Cent. Eur. J. Chem., 4, 56-67 (2006).

[12] E. R. Malinowski, D. G. Howery, Factor Analysis in Chemistry, Wiley, New York, 1980. pp. 32-82.

[13] Ü. Haldna, M. Grebenkova, Evaluation of different factor analytical methods for estimation of $\mathrm{p} K_{\mathrm{BH}}{ }^{+}$ and solvation parameter values of 2-hydrohybenzoic acid, Comput. Chem., 17, 241-243 (1993).
[14] Ü. Haldna, Estimation of the basicity constants of weak bases by the target testing method of factor analysis, Prog. Phys. Org. Chem., 18, 65-75 (1990).

[15] Ü. Haldna, A. Murshak, Estimation of the basicity constants of weak bases by the target testing method of factor analysis, Comput. Chem., 8, 201-204 (1984).

[16] A. Bagno, G. Lovato, G. Scorrano, Thermodynamics of protonation and hydration of aliphatic amides, J. Chem. Soc. Perkin Trans. 2, 1091-1098 (1993).

[17] M. Liler, Studies of nuclear magnetic resonance chemical shifts caused by protonation. Part II. Formamide and some $N$-alkyl and $N, N$-dialkyl derivatives, J. Chem. Soc. (B), 2, 334-338 (1971).

[18] M. Liler, Studies of nuclear magnetic resonance chemical shifts caused by protonation. Part I. Substituted acetamides and some $\mathrm{N}$-methyl- and $\mathrm{N}, \mathrm{N}$ dimethyl-derivatives, J. Chem. Soc. (B), 4, 385389 (1969).

[19] A. Bagno, V. Lucchini, G. Scorrano, Thermodynamics of protonation of $\mathrm{N}, \mathrm{N}$-dimethylthioamides in aqueous sulfuric acid, Can. J. Chem., 68, 17461749 (1990).

[20] A. Bagno, G. Scorrano, Acid-base properties of organic solvents, J. Am. Chem. Soc., 110, 45774586 (1988).

[21] R. A. Cox, L. M. Druet, A. E. Klausner, T. A. Modro, P. Wan, K. Yates, Protonation acidity constants for some benzamides, acetamides, and lactams, Can. J. Chem., 59, 1568-1573 (1981).

[22] B. G. Cox, A nuclear magnetic resonance study of the rates of protonation of dimethylacetamide and dimethylbenzamide in concentrated acid solutions, J. Chem. Soc. (B), 9, 1780-1783 (1970).

[23] H. M. Grant, P. McTigue, D. G. Ward, The basicities of aliphatic amides, Aust. J. Chem., 36, 2211-2218 (1983).

[24] S. J. Cho, C. Cui, J. Y. Lee, J. K. Park, S. B. Suh, J. Park, B. H. Kim, K. S. Kim, $N$-protonation vs $O$ protonation in strained amides: Ab initio study, $J$. Org. Chem., 62, 4068-4071 (1997).

[25] A. Bagno, Acyl group vs nitrogen protonation of carboxylic and non-carboxylic amides in the gas phase and water, J. Phys. Org. Chem., 13, 574-578 (2000).

[26] K. Yates, R. A. McClelland, Mechanisms of ester hydrolysis in aqueous sulfuric acids, J. Am. Chem. Soc., 89, 2686-2692 (1967).

[27] J. F. Bunnet, F. P. Olsen, Linear free-energy relations concerning equilibriums in moderately concentrated mineral acids. A simple method for estimation $\mathrm{p} K$ 's of weak bases, Can. J. Chem., 44, 1899-1916 (1966). 
[28] R. A. Cox, K. Yates, Excess acidities. A generalized method for the determination of basicities in aqueous acid mixtures, J. Am. Chem. Soc., 100, 3861-3867 (1978).

[29] R. A. Cox, Excess acidities, Adv. Phys. Org. Chem., 35, 1-66 (2000).

[30] E. S. Stern, C. J. Timmons, Electronic Absorption Spectroscopy in Organic Chemistry, Third Edition, Edward Arnold Ltd., London, 1970, p. 54.

[31] E. S. Eberhardt, R. T. Raines, Amide-amide and amide-water hydrogen bonds: implications for protein folding and stability, J. Am. Chem. Soc., 116, 2149-2150 (1994).

[32] R. A. Cox, K. Yates, Medium efects in protonation equilibrium studies. Accurate acidity constants using the excess acidity method, Can. J. Chem., 59, 1560-1567 (1981).
[33] B. S. Andonovski, G. M. Stojković, UV study of indole and 3-acetylindole in phosphoric and hydrochloric acid solutions, Acta Chim. Slov., 47, 349-362 (2000).

[34] L. P. Hammett, The effect of structure upon the reactions of organic compounds. Benzene derivatives, J. Am. Chem. Soc., 59, 96-103 (1937).

[35] R. W. Taft, Jr., Polar and steric substituent constats for aliphatic and o-benzoate groups from rates of esterification and hydrolysis of esters, J. Am. Chem. Soc., 74, 3120-3128 (1952).

[36] C. K. Hancock, E. A. Meyers, B. J. Yager, Quantitative separation of hyperconjugation effects from steric substituent constants, J. Am. Chem. Soc., 83, 4211-4216 (1961). 